UDC 130.2:37.013.73

NIKITENKO VÌTALINA

Candidate of Philosophical Sciences $(\mathrm{PhD})$, Assistant Professor of Foreign Languages Department, Zaporizhzhya State Engineering Academy (Zaporizhzhya, Ukraine) E-mail: vitalina2006@ukr.net

\title{
CONCEPTUALIZATION OF GEO-CULTURAL VALUES IN THE PROCESS OF TEACHING OF FOREIGN LANGUAGE
}

The article discusses the main geo-cultural values as a conceptof study in the teaching of foreign languages. The problem field of study is formulated; ideological foundations of harmonious development of the individual in the context of geoculture are formed, which are a prerequisite for successful mastering of a foreign language.

Key words: geoculture, geovalue, civilizational core, concept of research, semantic units, the teaching of foreign languages, social organism

Conceptualization of geo-cultural values in the process of teaching of foreign language: the social and philosophical dimension.

The article discusses the main geo-cultural values as a conceptof study in the teaching of foreign languages. The problem field of study is formulated; ideological foundations of harmonious development of the individual in the context of geoculture are formed, which are a prerequisite for successful mastering of a foreign language.

Key words: geoculture, geovalue, geobehavior, civilizational core, concept of research, semantic units, the teaching of foreign languages, social organizm Teaching process is inextricably linked with the culture and language is its value. It is its organic part and serves as an external factor of geo-cultural development. Therefore, in the present time geocultural values must be conceptualized for harmonization of teaching of foreign languages. The presence of values in the phenomena of culture and education is explained by the fact that they are the result of creative work, which is free of purposeful activity. The foregoing means that human activity, and especially the activities of production, are determined and directed by two fundamentally different factors: the actual material that determine its cause and ideal, i.e. those sought by the manufacturer. The objective of this article is to distinguish the concept of "geo-cultural values" as the main concept of this study. It is necessary to form a problematic field and determine the philosophical, ideological and methodological approaches to its study, as well as tools for scientific and research work. It must be noted that there are options of interpreting the main concept, such as " culture of geovalues" or "values of geoculture." For us two expressions mentioned above are one rate units of semantic analysis. We believe that the main concept - "geo-cultural values," holds in itself the whole mystery of the problem which is investigated and is compound of at least of three components,

(C) Nikitenko Vitalina, 2016 
namely the sense of the term: a) "values"; b) "culture" and c) "geo". It is necessary to extract and identify the phenomenon that interests us.

Discussion of the problem. Concept (Lat. - Conceptus - concept) in scientific knowledge - is definitely ordered minimum of ideas, which creates a conceptual diagram of a necessary concept ideas and communication between them creates the essence of conceptualization. It is a well known fact for researchers. We know also that the concept operates within the existing conceptual scheme mode logic circuits interconnected system "understanding-explanation" that makes certain steps interrelated actions researchers to advance the principles defined or specified. So, based on the foregoing, it is possible to form a leading criterion motivation to the concept of philosophical thinking, which is that it we need when we are facing a new, non-trivial situation and we have no samples and examples for further actions which are necessary to master a foreign language. Analysis is starting with clarifying the meaning of the term "value". Here we refer to the works of M.Berdyaev, S. Bulgakov, V. Soloviev, V. Rozanov, E. Fromm, W. Frank, J. Habermas and P. Yurkevich. The original axiological drama describes the philosophical reflections of M. Weber and A. Schweitzer, Spengler and M. Gadamer, H. Ortega y Gasset and K. Jaspers, Freud and K-G. Young, J-P. Sartre and Camus, J. Hayzinhy and A. Toynbee and others. The concept of value is considered by the transcendentalism (V. Windelband, H. Rickert), cultural and historical relativism (W. Dilthey, Spengler, A. Toynbee). Sociological interpretation of values was made by $R$. Dahrendorf, Kovalevsky, T. Parsons, Sorokin, R. Sheldon , B. Shilz. In addition, a number of works are devoted to cognition of the specific values in the various fields of knowledge: political, economic, legal, environmental, aesthetic, religious (E.V.Zolotukhina-Abolina., V.M. Zuev, V.S Krysachenko, A.F. Losev, M.I. Mihalchenko, V.G.Voronkova, A.V.Semashko, V.N. Shilov, Yu.Fedorov ). In recent years, intensified analysis of the value orientation of the individual in the process of formation and life was intensified (V.S. Bakirov, M.F.Holovaty, E.I.Golovakha, M.M.Moklyak, V.S.Pazenok, Y.E.Parnyuk, V.G.Tabachkovskyy, A.A Yaroshenko. A special layer keeps axiology scientific sources (R.G. Lotze, Friedrich Nietzsche, W. Windelband, H. Rickert, N.O. Losskyy, E. Cassirer, Soloviev, etc.). Condition of problems coverage of socio-philosophical analysis of culture as axiological phenomena in the process of teaching a foreign language by means of values is characterized by a certain ambiguity. On the one hand, there is a large bibliography on the philosophy of culture. On the other hand, its analysis shows that sufficient axiological reflection on culture phenomenon does not exist yet sufficiently developed as outlined area of philosophical investigation, which is solving an extremely important theoretical questions that have some relevance to foreign language teaching. Mainly that fact concerns the values. "Axiological shift" which is in educational space, at present contributes decisive nomination and development of philosophical thinking values issues as a special branch of pedagogical and philosophical knowledge. On the one hand, and on the other it is a way to return to the bosom of the national social science of general civilization values. This clearly demonstrates global scale or geo-cultural dimension of subject field research. In a 
further the category of "value" which indicates this phenomenon may be interpreted in at least three major ways: as a socio-cultural concept that describes the context of being an objective which takes place as a psychological concept and a logicalepistemological concepts which is a prerequisite for learning a foreign language. Already these multidimensionality categories set of values indicate on what this category concentrates a plurality of heterogeneous content, but at the same time there is something identical in problems. In other words, most authors agree, so it is difficult to point to a single one, that universal context within which to formulate and solve the problem of values, but almost all came together in one, in any context, arguments about the value of the principal, major is that we are talking about human values, or the values relating to human. Therefore, its impact is felt at all levels of the structural organization of the international community, and above all, the planetary, regional / territorial and national. Etymological analysis of a philosophical concept, as well as linguistic and semantic description of its properties, cannot be considered in identifying the philosophical content of the concept. But philosophical categorical meaning is different, usually from common one, getting to meet the needs of theoretical considerations specific character, particularly in learning of a foreign language. As N.N. Bakhtin noted, meaning is this or that answer to our question: "What does not answer any question does not have any content." The same idea was expressed by J.-P. Sartre : "Life is not a priori content. As long as you are not living your life, it is representing nothing, you do have to add meaning and value is nothing but you chose of this content "[1]. Further, when determining the value of a philosophical subject virtually all human social life (culture) in its various forms comes into consideration. Whatever culturological or sociological concept we would not have, a thing, an idea, a rule, a principle, a maxim, a symbol, an imperative etc., each of these concepts can be seen as basic in determining the intrinsic properties of the values that we use in teaching of foreign languages because they all bear the clearly value content. "Wide" (philosophical) definition of values as a generic in culture means that its status can be realized only in relation to such concepts as knowledge and being, as in value terms, disclosed content through cognitiveevaluative activity of man to life and reveals the meaning of corporate culture and including [2]. The concept of value, therefore, is the concept of a high level of abstraction that enables capture semantic relationships that occur between the different actors being in the act of identifying significance (evaluation) of individual reality, different social communities and society as a whole, which in fact, forms a cultural phenomenon. So we have a wide range of definitions of a value of educational, sociological, economic, cultural philosophical, psychological order. Important is proposed by $M$. Rokych distribution of values as terminal ones (values goals) and tools (value - means)which are to be guided in teaching of foreign languages. Also within the term of value it is actual to define such concept as "value system", which is defined as "a model of values of society or group in which individual values are interrelated in such a way that each of them is reinforced the other, and thus formed to agreed objectives [3]. The next step is mastering the main concept of this study is the term of "culture" that has a very long and complex history

(C) Nikitenko Vitalina, 2016 
in discourse of theoretical thought of becoming the world community. It has been used by the French Enlightenment in the 18th century, such as Voltaire (1694-1778), Jean Condorcet (1743-1794), German philosopher Johann Herder (1744-1803) and others. For them, culture is that was created by mankind in the course of its history, especially it concerns the material culture. It also included the human factor as its creator. The term "civilization" expresses the result of collective action, and the nature of the term "culture" has shifted to the individual and expresses its primarily spiritual, educational and morale quality. I.Kant, for example, defines culture as something that is for the benefit of humans, highlighting its two varieties: 1) "culture of skill" or "technical art", i.e. civilization; 2) "culture of education", that civilization, which forms a truly spiritual person develops more slowly than the "culture of skill". The merit of the German Enlightenment is also on a deep sense of spiritual connection which is necessary for the culture (its moral component) with religion. It is worth to remember Gotthold Lessing (1729-1781). "The education of the human race," which suggested that religious consciousness, being inseparable from morality, in different historical periods contains significant differences. The basis of geocultural processes - the development of universal norms and values that are enshrined in the relevant symbolic systems. It is noted that media geo-cultural trends primarily a science and education, and the media that is able to replicate the real-time cultural patterns around the world. As we have already noted, I. Wallerstein, who was the first to coin the term geoculture, understands the way of the world cultural space allocation of social groups that make up the nucleus of civilization existing in the world, societies with peripheral importance, and those that make semi-peripheral zones. In most cases geoculture is generated by some civilization. In some rare cases geoculture may go beyond one branch of civilization. In this case, some geoculture can be offered to humanity as an ideal cultural model. To realize the goal of our research it is extremely important that in international theoretical heritage there are two types of philosophical and historical concepts of culture - globally and locally world-historical. [3] Of course, to clarify the meaning of terms it is better to start with a philosophical sources, since they concentrate achievements of science in this area. The difference between culture and civilization is that culture and the result is a manifestation of the people's will expression or individual ( "cultured man"), while civilization is a set of achievements technology and the associated comfort ". We should note the following fact: geo-cultural values in are spiritual meaning units that reflect the needs of ordinary citizens or social formations, such as ethnic, national, regional, state, national, supranational and international entities in the means to meet their personal and collective social needs that materialize in geoculture and operate in the form of the people's interests as subject to the protect cultural-historical process and ready to spend and their energy, material and spiritual forces, that are their vital resources. In this case, the purpose of the study allows us to use them, the terms of "geovalues" and " geoculture " as synonyms, such as the analysis of scientific approaches to the study geovalues when evaluating and selecting methodological tools. Standards of geoculture and geobehavior as subject of philosophical research rarely become the subject of investigation. That is because they are semantic units 
have their otherness in the structure of personality, thanks to the needs, vision, consciousness, self-consciousness in its ideological culture and structure of society: social, political, military, cultural, axiological, ethical, environmental, finally, international areas and therefore take other forms of their own life, in the study of are involved, in addition to philosophy, the other sciences which we use successfully in the formation of personality while learning a foreign language.

\section{REFERENCES}

1. Voronkova V.G. The philosophy of globalization: sotsioantropological, socioeconomic and sociocultural dimensions. monograph. / Valentina G. Voronkova. - Zaporozhye: ZSEA Publishing, 2010. $-272 \mathrm{p}$.

2. Social study Encyclopedic Dictionary. In Russian, English, German, French and Check languages. Editor - coordinator - academician RAS H.V.Osypov. - M .: INFRA Editing group MNORMA, 1998. - $488 \mathrm{p}$.

3. Chumakov A.N. Globalization. The counters of the whole world: monograph. - 2nd ed .. rev. and dop.- M .: Prospekt, 2011. - 432 p.4.Hartyya of Earth (text) // Safety of EuroAsia. - 2001. - №2. $405 \mathrm{p} /$

НІКІТЕНКО, В. О. - кандидат філософських наук, доцент кафедри іноземних мов Запорізької державної інженерної академії ( Запоріжжя, Україна)

\section{КОНЦЕПТУАЛІЗАЦІЯ ГЕОКУЛЬТУРНИХ ЦІННОСТЕЙ У ПРОЦЕСІ ВИКЛАДАННЯ ІНОЗЕМНОЇ МОВИ: СОЦІАЛЬНІ ТА ФІЛОСОФСЬКІ ВИМІРИ}

У статті обговорюються основні геокультурны иінності як конщепт дослідження у викладанні іноземних мов. Сформульовані проблема галузі вивчення; формуються ідеологічні засади гармонійного розвитку особистості в контексті геокультури, яка є передумовою для успішного оволодіння іноземною мовою.

Ключові слова: геокультура, геоцінності, ичивілізаџійні ядра, конщепџія дослідження семантичного одиниць, викладання іноземних мов, сочіальний організм

Стаття надійшла до редакиії 20.01.16 р. Рекомендовано до друку 25.01.16 p. 